\title{
Employees of Greatness: Signifying Values in Performance Appraisal Criteria'
}

\section{Ylva Ulfsdotter Eriksson ${ }^{2}$}

Department of Sociology and Work Science, University of Gothenburg, Sweden

\section{Bengt Larsson}

Department of Sociology and Work Science, University of Gothenburg, Sweden

\section{Petra Adolfsson}

Department of Business Administration, University of Gothenburg, Sweden

\begin{abstract}
The spread of performance-based and variable pay systems has affected expectations on employee contributions and remuneration, which have become increasingly personalized and individualized. Based on a theoretical valuation studies approach, this study of performance-based pay systems in Sweden shows that performance appraisals are (e)valuations of employees' yearly performance in which they are prized and (ap)praised at the same time. Through a document analysis of performance criteria from four organizations, the study analyzes how values expressed refer to Boltanski and Thévenot's six orders of worth. The analysis resulted in a theoretical construction of a joint ideal of Employees of Greatness, against which employees are measured and remunerated. The existence of the ideal of employee greatness is explained by the increasing congruence of organizational ideals in private and public sectors, as principles from emotional and cognitive forms of capitalist organization are superimposed on traditional industrial capitalist organizational ideals.
\end{abstract}

\section{KEYWORDS}

Performance appraisal criteria / (e)valuation / orders of worth / performance-based pay

\section{Introduction}

he Swedish wage formation system has transformed in fundamental ways over the last four decades. Older ideals of equal pay for work of equal value have been replaced with individualized desert-based pay principles (Baccaro \& Howell 2017; Spano \& Monfardini 2018). The post-war model of centralized national wage bargaining was abandoned in the 1980s, and a coordinated system of sectoral national bargaining combined with local negotiations was established in the late 1990s (Baccaro \& Howell 2017). The principle of 'equal pay for equal work', based on nationally coordinated wage tariffs, was gradually supplanted by individualized desert-based principles

\footnotetext{
${ }^{1}$ You can find this text and its DOI at https://tidsskrift.dk/njwls/index.

${ }^{2}$ Corresponding author: Ylva Ulfsdotter Eriksson, Department of Sociology and Work Science, University of Gothenburg, Sweden. E-mail: Ylva.Ulfsdotter Eriksson@sociology.gu.se.
} 
of compensation (Bengtsson \& Berglund 2012, p. 86). Thus, public discourse on wage formation and the yearly pay raise turned away from solidaristic values and national coordination and became more focused on organizational productivity, flexibility, and individually differentiated wages related to employees' performance and contributions to the organization (Lapidus 2015; Thörnqvist 1998).

Previously, pay raises were a rather standardized activity following the ideals of bureaucracy and primarily based on merit, experience, and seniority. Nowadays, yearly compensations are based on individual performance appraisal reviews, in both 'liberated' firms and NPM-inspired public sector organizations (Madden \& Wekker 2017; cf. Chatelain-Ponroy et al. 2018; Eurofound 2016; Heneman 2003; Townley 1997; Ulfsdotter Eriksson et al. 2020). Current wage formation puts increased responsibility on organizations to decide what that is valued in employee performance, which according to Lapidus $(2015$, p. 3), is giving 'greater power to managers and employers at the expense of workers and the union'. Still, the foundations of performance-based pay are often explicitly stated in collective agreements, not least in the public sector, which has transformed drastically during the transformation of the Swedish welfare state in recent decades and is now ahead in using performance-based pay systems (cf. Larsson et al. 2012).

Collective agreements stipulating individual and differentiated pay concerns about $50 \%$ of the workforce, and are above all common for public employees of which $60 \%$ were covered by figureless agreements in 2019 (SNMO 2020). The other 40\% had agreements with a wage pot but without guarantees on the individual level. For bluecollar workers, especially in the manufacturing industries, wage determination remains centralized (Karlson et al. 2014; Kjellberg 2019; SNMO 2020).

Employees with individual and differentiated pay are subjected to yearly performance appraisal reviews, and performance-based pay put a greater focus on organizations' valuation of individual employees (Bengtsson \& Berglund 2012). Jensen and Prieur (2016) discuss how transitions in working life have changed the expectations of employees. Today's organizations values 'personal traits, such as motivation, flexibility, involvement, and creativity' (Jensen \& Prieur 2016, p. 100; cf. Fleming \& Sturdy 2009; Rees Davies \& Flink 2014). Thus, employees are not only renting out their bodies, but increasingly also their cognitive attention, personal involvement, and emotions; consequently, the 'personal is commodified and transformed into a competitive asset' (Jensen \& Prieur 2016, p. 104f.; cf. Hochschild 1983; Illouz 2007, 2018; Moulier Boutang 2011).

The title of this article is a wordplay based on 'Les economies grandeur', the French subtitle of Boltanski and Thévenot's seminal book De la justification (On justification 2006/1991). Thus, the study aims to describe and explain what employees are expected and encouraged to be and do to be recognized as highly valued. By focusing on what traits, attitudes, behaviors, and skills that are prized and (ap)praised in performance appraisal criteria, this study reveals which ideals of 'employee greatness' organizations set up to make employees perform and improve continuously, which contributes to an understanding of how the transformations of work affect expectations of employees (Rees Davies \& Flink 2014). More precisely, the purpose is to explore what signifying values and orders of worth (Boltanski \& Thévenot 2006) are present in the performance appraisal criteria used when organizations evaluate employees in yearly salary reviews.

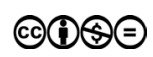


The empirical material consisted of performance appraisal criteria from four large Swedish organizations: a municipality, a regional hospital, a state agency, and a multinational manufacturing company. The first cycle of coding in the qualitative content analysis was based on the six orders of worth in Boltanski and Thévenot (2006), whereas the second cycle of coding inductively revealed aspects that signify values within these original six orders of worth. Overall, the organizations evaluate and value quite similar behaviors, attitudes, traits, and skills, even though they belong to different institutional fields (Thornton et al. 2012; Townley 1997). Signifying values of industrial worth are common, but organizations also value and evaluate employees on domestic, inspired, civic, fame, and market worth. It seems that organizations operating in fields traditionally dominated by bureaucratic and professional logics adapt to isomorphistic pressures stemming from overall changes in norms and ideas of industrial, emotional, and cognitive capitalist organizations (Jensen \& Prieur 2016; cf. Hochschild 1983; Illouz 2007, 2018; Moulier Boutang 2011). The present study contributes to valuation studies (Antal et al. 2015; Beckert \& Aspers 2011; Beckert \& Musselin 2013; Karpik 2010; Lamont 2012) by analyzing organizational valuation of labor.

The article begins with a discussion of the theoretical points of departure of the pricing, prizing, and (ap)praising of labor and different aspects of capitalism. This is followed by a description of the methods and materials and a presentation of the findings. The article ends with a concluding discussion about what signifying values construct and constitute the ideal of 'employee greatness' used in contemporary organizations for employees to strive toward by continuously improving.

\section{Pricing, prizing, and (ap)praising labor}

Even though pay systems vary between institutional contexts, many organizations apply performance-based or variable pay systems (Eurofound 2016; Madden \& Vekker 2017). Yearly performance appraisal is a response to organizations' quest to systematically measure both what the employee has achieved and how the task was carried out (Storey $\&$ Sisson 2005). Thus, organizations develop and use performance appraisal with welldefined evaluation criteria when striving for objectivity and transparency in the evaluation of employees. Result-based pay (such as bonuses and profit sharing) and piece-rate systems are rewards solely based on quantitative measures. By contrast, performance appraisals focus on qualitative aspects of behaviors, attitudes, and traits, and have been criticized for being subjective, since the evaluations may be influenced by personal judgment and relations (Jirjahn \& Poutsma 2013). However, qualitative appraisal criteria are not meant to be neutral and objective. They constitute 'the meaning of performance /.../ discursively', and, as such, are key signifiers of what that is valued in the organization and in revealing what makes up a worthy employee (Hoedemaekers \& Keegan 2010, p. 1022). Thus, performance appraisal criteria disclose what the organization values in terms of performance, traits, and behaviors.

Valuation theory highlights the interconnection between quantitative (economic) values and qualitative and multiple (social) values, between estimating and esteeming (Dewey 1939; cf. De Munck \& Zimmerman 2015). Deciding the value of labor is a complex process involving several evaluative moments (Gomez-Mejia et al. 2010). The two major steps are the evaluation of the worth of the job and the evaluation of the worth 
of the worker. Job evaluations are generally based on factors such as job qualification demands, the complexity of task, responsibilities, and market value in connection to supply and demand, and pricing of jobs with similar qualification requirements (GomezMeija et al. 2010).

The difference between job evaluation and individual performance-based pay corresponds to the theoretical distinction between pricing, prizing and praising (Stark 2017). The pricing of jobs relates strongly to institutional and regulative frames while prizing and praising concern the evaluation of the individual in performance appraisal reviews (Beckert 2011; cf. Heneman 2003). Pricing sets the basic wage from general job evaluations and market contexts, whereas the prizing and praising highlights the competitive, retrospective premiering and recognition aspects, as well as the forward-looking motivating aspects of performance-based pay. Accordingly, pricing explains the differences in wages between different kinds of jobs. For instance, pricing explains the logic behind the fact that a headmaster in a primary school has a monthly wage corresponding to $€ 4000-5000$, while a pre-school teacher earns €2500-2850 per month (Larsson et al. 2017). The pay grade lays the ground for basic pay and entry wages for new employees. Unlike basic pay, where the job is the focal point of the evaluation, performance-based pay departs from the employee's accomplishments, results, and achieved goals. Thus, the wage differences within a job are a result of the performance-based pay. This part of the salary is an example of prizing since it aims to reward the most contributing employees and because of the competitive elements. Therefore, differences in performance and prizing explain why one pre-school teacher gets a pay raise of $€ 76$ per month while his or her colleague only receives a monthly raise of $€ 19$. As Stark (2009, p. 9) puts it, 'payment systems are about recognition as well as about monetary rewards' (cf. Voswinkel 2012). This captures the praising aspect of the appraisal to also motivate and create engagement among employees.

Wage signals both the economic value of a job and the worth of an employee. The concept of worth encompasses multidimensionality that value never captures: 'Valuing something means measuring and comparing it according to a scale. Worth is a covering concept, encompassing all the different scales through which the value of an object or event can be assessed' (Aspers \& Beckert 2011, p. 6). Valuation is about 'commensurating' something rather incommensurable, by selecting, estimating, judging, abstracting, and ranking qualitative differences into a quantifiable scale, such as a pay raise (Beckert $\&$ Musselin 2013). Several cognitive and normative devices and tools are required to make such a conversion from values (or worth) to value (Karpik 2011).

(E) valuations are social and cultural practices where the value of an object or a person's contribution is judged vis-à-vis several legitimate evaluation criteria (Lamont 2012, p. 205). This definition of the valuation process highly resembles organizational routines of performance appraisal practices (Armstrong 2009; Storey \& Sisson 2005). In the yearly performance appraisal, employees and managers evaluate how well an employee has met goals and targets as well as norms, behaviors, attitudes, skills, and traits that are valued in the organization (Gomez-Meija et al. 2010). Hence, performance-based pay is a valuation process where the worth of the laborer is measured against several criteria that jointly make up a construct of the 'employee of greatness', as an ideal to which continuously strive toward. Thus, wage policies and performance appraisal criteria are tools, not only for evaluation but also for communicating, governing, and controlling labor in 'liberated' organizations (Boltanski \& Chiapello 2005).

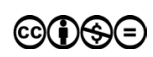




\section{Industrial, emotional, and cognitive capitalism in organizations}

The change in direction toward liberalized industrial relations is not a uniquely Swedish development (Baccaro \& Howell 2017). Boltanski and Chiapello (2005) suggested that general ideological changes, and the establishment of a new value system, have made the individualization of labor possible. They discussed how the critiques directed at the second wave of capitalism (1940-1970) were successively incorporated by organizations, laying the ground for the third wave of capitalism from the 1980s and onwards. For instance, hierarchical bureaucracies were criticized during the 1960s for being dominantly controlling, with managers too technically focused on numbers and quantitative objectives. This critique was met by new organizational ideals, such as flat structures, emphasis on organizational culture, and visionary and charismatic leadership ideas. For the laborers, there was a new emphasis on flexible and autonomous workers and innovative teams, and the idea that the customer was the 'real' employer (Sennett 1998).

According to Boltanski and Chiapello (2005, p. 80), the 'liberated firm' meets challenges in exerting control. An apparent part of the solution is routines of self-control: increased focus on engagement, motivation, and participation circumscribes the employee and calls for the development of commitment, loyalty, of enjoying work, and the pleasure of doing it. On the labor market level, this development is paralleled by the discourse of employability that emphasizes the individuals' responsibility to be and stay attractive. Formal merits are no longer sufficient, and new capabilities must be acquired and improved through lifelong learning and flexibility. This may be achieved by showing the 'right' attitude of 'adaptability, versatility, showing an entrepreneurial attitude, and through being service-minded and accepting continuous evaluation and ranking' (Garsten \& Jacobson 2004, p. 11). In the new world of work, employees are expected to be authentic, self-developing, participating, self-regulating, creative, capable of teamwork and networking (Boltanski \& Chiapello 2005; cf. Hoedemaekers \& Keegan 2010; Jensen \& Prieur 2016).

In contrast to organizations operating in industrial capitalism, when personal traits were of less interest and workers were required to control emotional expressions, the third wave of capitalism emphasizes emotions, cognition, self-reflection, and personal traits as vital employee resources (Illouz 2007, 2018). The quest for employees to communicate, cooperate, and network requires strategic emotional labor. The valued asset of being socially competent concerns the ability to understand and meet clients and customers in controlled but authentic forms. In line with Hochschild (1983), Illouz (2018, p. 9) argued that emotions are part of the production process, and the concept of emotional capitalism captures the interlinkage of emotions and business activities. Tests of personality, cognition (IQ), and emotional intelligence (EQ) are examples of legitimate and sanctioned tools used in recruitment and evaluations of job performance (Illouz 2007).

Apart from extracting surplus value from emotional labor, contemporary organizations are also increasingly dependent on laborers' cognitive, intellectual, and creative capacities since 'knowledge and innovation /.../ plays a determining role in generating profit' (Moulier Boutang 2011, p. 57). Cooperation and communication abilities are additional examples of laborers cognitive resources (Jensen \& Prieur 2016). The concept of cognitive capitalism emphasizes the immaterial value accumulation, which relies 
heavily on employees' capacity and competence in the area of innovation, creativity, and networking. The immaterialization of labor not only makes it more difficult to govern and monitor workers, but also to account for employees' value and to remunerate individuals: 'What is the value of knowledge in a firm - and the value of its reputation, of its client networks, and harder still to assess, of its innovative potential' (Moulier Boutang 2011, p. 141).

\section{Material and methods}

A qualitative document analysis of performance appraisal criteria was conducted to explore, describe, and explain what organizations evaluate and values in employees. Criteria are seen as carriers of ideals, values, and discourses of what makes up a worthy laborer (Dewey 1939). These values are also essential for understanding changes in the discourse of labor as a commodity (Jensen \& Prieur 2016) and the prizing of labor (Beckert 2011). Values expressed in performance criteria mirror that of what is worthy on the labor market more generally. This is in line with how Garsten and Jacobsson (2004, p. 2) argued that the discourse of employability 'also illustrates a shift from a systemic view of the labor market to a focus on individuals and their qualities'.

\section{Material - performance appraisal criteria}

The analysis draws on documents of performance appraisal criteria in four large Swedish organizations, which were selected to provide a variety of organizational contexts and institutional logics (Thornton et al. 2012). The first was a municipality (Muni.), with childcare, schools, elderly care, and other citizen services as its core activities. The second was a regional hospital (Hosp.) with professional and semiprofessional staff in advanced health care. The third was a state agency (Gov.) responsible for service and control toward individuals and organizations, with educated officers performing bureaucratic case handling. The fourth was a private manufacturing company (Mfr.C) that develops, produces, and sells goods on a global market. The performance appraisal criteria used in the respective organization were general and was thus used to evaluate practically all employees within the public organizations, and all white-collar employees within the manufacturing company.

The routines of the yearly salary review differ somewhat in the organizations, as do the evaluation tools used in the performance appraisal. It is not the systems or the instruments per se that are studied in this article, but what signifying values they express. The focus lies on the evaluative content, and the ideals and values, expressed in the performance criteria. Even if the performance evaluation systems differ, they have similar basic principles, in that employees are evaluated on several traits and behaviors (see Table 1).

Employees in the municipality (approx. 10,000) are evaluated on five overall performance criteria that are merged into three main criteria. The criteria are qualitative and the municipality expresses no quantitative measures or articulated goals. Performances on each criterion are graded through a continuous measurement scale guided by three reference points. The municipality has a similar set of general criteria, with one 
Table I Overview of criteria and grading in the four organizations

\begin{tabular}{|c|c|c|}
\hline Organization & Main criteria and specifications & Grading \\
\hline Municipality & $\begin{array}{l}\text { - Professionalism: Knowledge and quality of work; Goal and } \\
\text { result oriented } \\
\text { - Learning and Development: Develops works methods; } \\
\text { Develops competence vis-à-vis business needs } \\
\text { - Engagement and Behavior. An approach that creates security, } \\
\text { enthusiasm, openness and good behavior }\end{array}$ & $\begin{array}{l}\checkmark \text { Exceeds the } \\
\text { requirements } \\
\checkmark \text { Meets the } \\
\text { requirements } \\
\checkmark \begin{array}{l}\text { Needs to } \\
\text { develop }\end{array}\end{array}$ \\
\hline $\begin{array}{l}\text { Regional } \\
\text { hospital }\end{array}$ & $\begin{array}{l}\text { - Professionalism: Improved results and good quality } \\
\text { - Development:The business being brought forward through } \\
\text { competence and innovation } \\
\text { - Collaboration: For respectful relationships }\end{array}$ & $\begin{array}{l}\checkmark \text { Exemplary } \\
\checkmark \text { Good } \\
\checkmark \text { Needs to be } \\
\text { improved }\end{array}$ \\
\hline State Agency & $\begin{array}{l}\text { - Professionalism, result-oriented and contributes to business goals } \\
\text { - Understands the role and collaborates with others for the } \\
\text { benefit of the whole } \\
\text { - Is innovative and ready to change } \\
\text { - Shares knowledge and experiences } \\
\text { - Talks and writes objective and is easy to understand } \\
\text { - Takes responsibility for the own development }\end{array}$ & $\begin{array}{ll}\checkmark & \text { Excellent } \\
\checkmark & \text { Good } \\
\checkmark & \text { Acceptable } \\
\checkmark & \text { Insufficient }\end{array}$ \\
\hline $\begin{array}{l}\text { Manufacturing } \\
\text { Company }\end{array}$ & $\begin{array}{l}\text { - } \quad \text { Core values: Respect, excellence, responsibility } \\
\text { - Leadership capabilities: Perspective, performance, people } \\
\text { engagement, personal impact } \\
\text { - } \quad \text { Functional capabilities: (Occupationally specific) } \\
\text { - Objectives: (Individually set quantitative or qualitative goals) }\end{array}$ & $\begin{array}{ll}\checkmark & 4 \\
\checkmark & 3 \\
\checkmark & 2 \\
\checkmark & 1\end{array}$ \\
\hline
\end{tabular}

extra criterion for the evaluation of managers (not included in the analysis). A goal for the organization is to operationalize the general criteria vis-à-vis the different operating areas (e.g., childcare, school, elderly care) to make them more profession-specific (e.g., assistant nurse or nurse). When the fieldwork was conducted, they had specified the general criteria only for childcare in which they had slightly different wordings in the criteria for pre-school teachers and child-minders. A survey study conducted showed that about $40 \%$ of the employees had specified ones and equally many used the general appraisal criteria (Ulfsdotter Eriksson et al. 2019).

The regional hospital has three general performance criteria, which are used for thousands of employees in the whole region and that apply to both managers and employees. The criteria are to be translated within the units, by managers in collaboration with employees, to meet overall organizational goals and assignments. The units are multi-professional (physicians, nurses, assistant nurse, etc.) and the same criteria are used regardless of profession. The three main criteria are operationalized into 11 subcriteria and assessed in three grades. The organization stresses that assessments of employee performance are both quantitative and qualitative, but the definitions are all qualitative. The hospital also expresses expectations on units to meet several quantitative goals set for the whole organization as well (such as the number of waiting hours in the ER).

The state agency (with approx. 10,000 employees) has six main and general performance criteria for all different kinds of employees (and one extra for managers, which is 
not analyzed). Within each main criteria, performances are measured on a four-graded scale. Besides the qualitative evaluations, the agency also evaluates employees quantitatively, using information from administrative systems that reveal how employees conduct their tasks and contribute to the agency's overall numeric goals.

The manufacturing company has four major performance categories, with several criteria in each. Only one of them ('Core values') is general for all white-collar employees - the blue-collar workers in the production plant were covered by other pay principles. Regarding 'Leadership capabilities', all employees are evaluated on two to four selected criteria, whereas managers are to be evaluated on all criteria. Statements uttered in these criteria were included in the analysis. The category 'Objectives' consists of individually set goals, whereas 'Functional capabilities' are position- and profession-specific skills and under development in the organization (not analyzed). The latter was still under development and therefore not used for all. Within these four categories, employees are graded numerically, most commonly on a scale of 1-4.

\section{Qualitative content analysis}

The analytical method used was qualitative content analysis (Schreier 2013). For the analysis, the following steps were taken: All written statements from the selected performance criteria documents in all organizations were listed in Excel. All kinds of statements were included: the rubric or general theme of the criteria, the criteria as such, and the various ways they were described through examples and definitions. The first cycle of coding was theoretically driven, in which Boltanski and Thévenot's (2006) six orders of worth were used as inspiration. It aimed to identify the presence of the worlds of worth in the performance appraisal criteria. All statements, varying between 30 and 80 in the different organizations, were coded deductively as belonging to either of the six worlds of worth, depending on the kind of value that was expressed: industrial, market, domestic, inspired, fame, or civic. When a criterion contained two or more statements connoting different values, it was divided and the identified values were coded accordingly. For instance, 'Build trust and good relations both externally and internally', was divided into (1) build trust and good relations externally, and (2) build trust and good relations internally, as they signal values that belong to different regimes corresponding to (1) fame and (2) domestic. In the second cycle coding, the deductive analysis was supplemented with a more inductive, or grounded approach, identifying and distinguishing the signifying values within each world of worth. This data-driven analysis revealed more nuanced and richer descriptions of what is valued in performance appraisal reviews (Braun \& Clark 2006). The analysis disclosed 19 such aspects within the original six orders of worth.

In The new spirit of capitalism, Boltanski and Chiapello (2005) suggested a seventh world of worth - the Project Cité - which aimed to capture recent changes in work and society. The Project Cité was, however, not used in the analysis, as it seems to be more of an empirical type as compared to the six original orders of worth, which were founded on philosophical texts and thus seem to be more of ideal types, that is, theoretical abstractions that are mutually exclusive (Boltanski \& Thevenot 2006). Therefore, the Project Cité appears to be somewhat of a combination of the original six and not 'a world' that can be put on par with them at the same level of analysis.

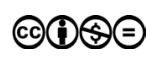




\section{Aspects of worth in performance appraisal criteria}

Performance criteria are means to standardize and define warranted and ideal traits, attitudes, behaviors, and skills, and are therefore instruments to communicate ideals and (e)valuate and control labor. In that respect, and on a general level, all kinds of criteria employers use are connected to the Industrial World, which is centered on organization and productivity. However, instead of minimizing diversity by subsuming all criteria as industrial worth, the present study aimed to grasp the multidimensionality of worth within work organizations (Boltanski \& Thévenot 2006). The results are presented 'world by world' in which the revealed aspects, or signifying values, within each worth are presented and exemplified. The findings end with a summary that shows the presence of the aspects of worth in the four organizations.

\section{The industrial world of worth}

Industrial worth entails all that which commonly defines a formal organization and its expected outcomes: tasks, production, coordination, and control (Mintzberg 1983). It is characterized by terms like efficiency, capacity, competence, function, and adaption - all those things that make the cogwheels in the machinery work smoothly and with a satisfying output. In the analysis of performance criteria, statements that stress goals, performance, competence, qualifications, and functions were identified as signifying values of industrial worth since they originate from the Industrial World. The analysis disclosed four aspects of worth: Goal Orientation, Quality of Performance, Knowledge \& Competence, and Contribution to Team Performance.

Performance appraisal reviews usually connect to an individual development plan in which the employee and the manager set goals for the coming year. Goal Orientation captures goal fulfilment and the responsibility to ensure the employee follows the plan and delivers. Being goal-oriented and taking on the responsibility to reach goals has to do with employees' self-control, which, according to Boltanski and Ciapello (2005), is warranted within liberated firms and organizations with a low degree of direct control from superiors. Performance appraisal criteria aim to control if and how the employee has fulfilled the objectives. For instance, the state agency values employees that 'Works efficiently and productively against set goals', while the hospital stresses that 'You take responsibility for your individual development plan and your results'.

Quality of Performance criteria relates to traits and behaviors aiming at doing highquality work and striving to do even better. The manufacturing company values employees who contribute to '[the] pursuit of excellence' that is intended to 'lead us to new levels of professionalism'. The state agency and the municipality use 'professionalism' as the main criterion for quality and, for the latter, 'high quality' is the main part of the definition of the 'professionalism criterion'. Professionalism is a common performance criterion (Ulfsdotter Eriksson et al. 2019) and a prevalent value in organizations more generally. Also, and as discussed by Fournier (1999) and Evetts (2011), professionalism is increasingly used as a discursive device to manage, control, and discipline employees.

Knowledge \& Competence concerns values of having, using, and acquiring the knowledge needed and developing skills to realize organizational results. Continuous learning is also a signifying value in line with contemporary ideals of lifelong learning 
and employability (Boltanski \& Chiapello 2005; Garsten \& Jacobsson 2004; Moulier Boutang 2011). In the performance appraisal criteria, statements like the value of having 'good professional skills and can translate these into practice' (Muni.), to 'take responsibility for and develop your skills' (Hosp.), or 'consistently thrive to get better' (Mfr.C.) are examples of this aspect. The state agency emphasized that employees should 'Keep[s] well informed about developments in the own field of work and actively look[s] for ways for the own competence development'.

Contribution to Team Performance captures values expressing the need for collaboration, to contribute to the team, and that every single employee is part of the whole. Thus, these aspects are related to task-fulfilment and joint productivity rather than more relational aspects of teamwork, which as such are classified as belonging to other regimes (below). The hospital put a lot of emphasis on the value of being capable of contributing to the team, which may be explained by the fact that, since the 1990s, Swedish hospitals have to a large extent organized work in multi-professional teams (Lindgren 2001). The hospital stresses the value of employees sharing 'You take full responsibility in the work, to "not sneak away"' and 'Cooperation in the business area', while the state agency stresses the need to' Understands one's role and interacts with others for the whole'. The manufacturing company values employees' ability to 'act as a team player', and the municipality the importance for employees to 'Use each other's knowledge to develop effective cooperation'.

\section{The domestic world of worth}

The word domestic originates from the Latin domus (house) and indicates things belonging to the house. In the analysis, domestic was used in this conveyed meaning of belonging rather than, as Boltanski and Thévenot suggested (2006, p. 164), the 'hierarchical relations among people' reached by for instance the use of titles, traditions, and hierarchies. The analysis of criteria belonging to the Domestic World captures values that focus on various kinds of relationships within the organization: between employees and teams and between employees and the employer. The joint efforts to create a good working environment are also a signifying value of the Domestic World (cf. harmony in Boltanski \& Thévenot 2006, p. 175). The analysis disclosed three aspects of domestic worth, all of which concern loyalty: to co-workers, the workplace, and the organization. It unfolds values relating to loyalty, trust, attention, good manners, and behaviors between employees and the employer respectively (cf. Moulier Boutang 2011).

Loyalty to co-workers concerns offering 'help and support' to colleagues (Muni.), or being able to 'provide and take feedback in a constructive manner' (Hosp.). The manufacturing company values employees who 'give people responsibility' and hold them 'accountable'. Also, the state agency values reliability and the capacity of 'Building trust and good relationships'. Trust is a 'term for self-control since it designates a trustworthy relationship' (Boltanski \& Chiapello 2005, p. 83).

Being loyal to the workplace also signifies a worthy employee and emphasizes the ability to take responsibility for a good and sound working environment. The state agency values an employee who 'contributes and assists for a collaborative climate characterized by openness, respect, good treatment'. 
Loyalty to the organization is expressed in criteria from the municipality and the manufacturing company. The former stresses 'commitment', which is an aspect of organization loyalty (Furåker 2012). The latter goes further and values employees who have 'a sense of ownership' are 'proud of the organization and its products' and supportive to decisions. Being loyal to decisions is in line with how Boltanski and Thévenot (2006) characterize worth within the Domestic World as they stress the kind of obedience that encompasses hierarchical relations. It is also in line with the employee's self-control inevitable in the liberated firm (Boltanski \& Chiapello 2005).

\section{The inspired world of worth}

Boltanski and Thévenot (2006, p. 159ff) argued that inspired worth 'cannot be measured' in an industrial form: 'In the inspired state of worthiness, beings are not subject to industrial measures, reasons, determinations, or the certainties of technology'. They claimed that, for individuals to access an inspired state, they need to be able to 'break free of habits and routines', and be prepared to welcome changes. Still, drawing on the performance appraisal criteria, organizations both seem to value and evaluate inspiring behavior. In the criteria, inspired worth was expressed by words like inspiration, creativity, passion, feelings, original, curious, inventiveness, uniqueness, openness, question, intuition, and genius.

Four aspects of inspired worth were disclosed: Curiosity, Driven, Innovation, and Inspiration. Curiosity is about the value of employees that are open for and act on change. Worthy employees are 'curious and open' (Muni.) and ready and prone to change (Muni. \& Hosp.). Further, a valuable employee is Driven - 'in your work both inside and outside your own workplace' (Hosp.), 'has urgency', and is 'hungry to lead and change the game' (Mrf.C.). Innovation has been a buzzword in the last decade and it is not surprising that innovation is a signifying value of a worthy employee. Innovation is the ability to find solutions, be creative, and develop new working methods. Employees in the municipality are, via performance appraisal criteria, encouraged to 'develop working procedures and methods', while the hospital values employees who 'evaluate existing working methods /.../ and contribute to development'. The state agency evaluates and values employees who have one ear to the ground to catch up on 'needs in society and the daily work, draws conclusions and initiates and drives changes'. The fourth aspect of inspired worth is Inspiration. Valuable employees in this respect contribute with 'a can-do attitude', to 'engage others' and 'empower people', as well as recognized the need to have fun at work (Mfr.C.). The municipality expressed something similar, stating that valued employees 'Strengthen and put forward positive attitudes and approaches'.

\section{The civic world of worth}

Civic worth is about the collective good rather than the individual (Boltanski \& Thévenot 2006). Unions, social movements, and actions streaming from the collective will, solidarity, and representativeness are examples of civic worth. On the individual level, it mainly concerns elected representatives, and individuals 'become worthy when they /.../ make themselves the expression of a general will (Boltanski \& Thévenot 2006, p. 187). 
With this definition, civic worth primarily concerns the representation of the collective. In the present analysis, the civic worth was interpreted more broadly to make it useful on the individual level, yet still in the realm of the well-being of others. The analysis disclosed three aspects of civic worth - Stakeholder Perspective, Civil Behavior, and Ethical Behavior, which in different ways include signifying values of the common good and the common will.

Stakeholder perspective was primarily valued in the manufacturing company, which appreciated employees who can 'take a broad stakeholder perspective' and 'to walk in the shoes of the customer'. Also, the municipality and the state agency stressed that employees should be attentive to clients. The former valued the intention 'To work /.../ towards those that we are for' and the latter that they valued employees that were 'Acting on the basis of the clients and the citizen's perspective'.

To perform and behave in civil ways was related to meeting clients and customers with integrity and respect and responding well to their needs and requests. Ethically oriented performance appraisal criteria further stress the ability of good judgment (Muni.) and to value diversity (Mrf. C. and Gov.). The manufacturing company also stressed the ability to 'Consider how our actions will affect others, inside and outside our company, now and in the future', which is a value strongly related to Corporate Social Responsibility (CSR). CSR has been described as a buzzword in global companies with profit-making organizations taking or expressing social and environmental responsibility (Biswas et al. 2017). According to Biswas et al. (2017, p. 37), 'the only way capitalism could survive and humanity prosper was by becoming responsible vis-à -vis the environment, society and communities across the world'. CSR is an example of how organizations steer and govern with social values and norms, both internally and externally.

\section{Worth in the market world}

Markets are about business, economic transactions, money, buyers and sellers, market share, profits, success, and competition (Boltanski \& Thévenot 2006). Actions are motivated by desire and being a winner. The analysis revealed three aspects of a market's worth in the performance appraisal criteria: Desires \& Needs, Expand Business, and Business Knowledge. Signifying values of market worth aspects were absent in the public sector organizations, with one exception: the state agency had a criterion stressing sensitivity of the market in that it valued employees who can 'Contribute[s] with knowledge of the outside world's requirements and needs', which is an example of the Desires \& Needs aspects. In a similar way, the manufacturing company values employees who 'actively search opportunities based on customer needs' and 'exceed the expectations of our customers'.

In the manufacturing company, it is also valuable to strive to Expand Business, by seeding and acting on opportunities, and to express Business Knowledge by showing business acumen and making 'sound business decisions'. That the private organization values market worth is not surprising as it acts on the open market, in contrast to the public sector organizations. On the other hand, several operations commonly conducted within municipalities and regional hospitals have, since the deregulation of the 1990s, faced competition from the private sector (Larsson et al. 2012). In this respect, it would not have been surprising if the public organization also valued market-oriented 
behaviors, as they are under competition from private organizations in the same line of business.

\section{Worth in the world of fame}

No organization is free from the opinion of others (Boltanski \& Thévenot 2006). Worth in the World of Fame covers public relations and branding: how the organization presents itself and how it is perceived and recognized by others. It concerns visibility, success, positive attention, recognition - all in an effort to achieve and maintain a good reputation. Internal and external branding is integrated in contemporary organizations and involves not only departments of marketing and information, but also more or less the whole organization. According to Biswas et al. (2017), branding an organization is as much about protecting its external and public reputation to secure market positions and attract potential talent as it is about ensuring that employees comply and agree with organizational values and norms. Worthy employee behavior in this respect is about supporting a good image of the organization. Two aspects of the worth of fame were disclosed in the analysis: Goodwill and Communication. Both concern external branding and the values of communicating appropriately, purposeful, and convincingly with customers, stakeholders, and the public.

Goodwill was most clearly emphasized by the state agency in the criterion 'Building trust and good relationships externally'. An important component in achieving and keeping goodwill is Communication, the second aspect of the worth of fame. The state agency stressed communicative aspects in several different statements. Besides being 'skilled in adapting communication to the recipient, situation and context', it was also valuable to communicate 'objectively', and 'easily' and in ways that are 'comprehensible' and 'legally correct'. For employees at the manufacturing company, it was valuable to 'Convey the message' and communicate 'effectively'.

The presentation of the findings has shown that organizations use values that may be traced back to Boltanski and Thévenot's six orders of worth in the performance appraisal criteria. Taken together, organizations ask for a plethora of behaviors, traits, attitudes, and skills in the performance appraisal review. The next section contains a summary of how the different aspects identified within the six orders of worth are presented in the respective organizations, allowing for a comparison between them as well.

\section{Multiple valuations of worth at work}

In this section, the findings are summarized in a presentation of how prominent the different orders of worth and the aspects within them are in each of the four organizations (see Table 2). Taken together, signifying values within industrial worth were the most prominent; within this, the most common aspects were Goal orientation, Knowledge $\&$ Competence, and Contribution to Team Performance. Performance criteria stressing loyalty of various forms relating to domestic worth were also quite common in all organizations, as is the signifying values within inspired worth in which curiosity and innovation were the most emphasized. Regarding worth from the Civic World, stakeholder's perspective and civil behavior were most strongly emphasized. Still, the 
hospital did not include any criteria signaling the value of stakeholder perspective, and all but the municipality had included aspects of ethical values. WORTH belonging to the market or the World of Fame was the least prominent, but still present in two of the organizations.

Table 2 A summary of aspects within the six orders of worth's and their presence in the organizations

\begin{tabular}{|c|c|c|c|c|c|}
\hline & Aspects & Municipality & \begin{tabular}{|l|} 
Regional \\
Hospital
\end{tabular} & $\begin{array}{l}\text { State } \\
\text { Agency }\end{array}$ & $\begin{array}{l}\text { Manufacturing } \\
\text { Company }\end{array}$ \\
\hline \multirow{4}{*}{$\begin{array}{l}\text { Industrial } \\
\text { worth }\end{array}$} & Goal Orientation & & & & \\
\hline & Quality of Performance & & & & \\
\hline & Knowledge \& Competence & & & & \\
\hline & Team Contribution & & & & \\
\hline \multirow{3}{*}{$\begin{array}{l}\text { Domestic } \\
\text { worth }\end{array}$} & Loyal to Co-workers & & & & \\
\hline & Loyal to Workplace & & & & \\
\hline & Loyal to Organization & & & & \\
\hline \multirow{4}{*}{$\begin{array}{l}\text { Inspired } \\
\text { worth }\end{array}$} & Curiosity & & & & \\
\hline & Drive & & & & \\
\hline & Innovative & & & & \\
\hline & Inspiration & & & & \\
\hline \multirow{3}{*}{$\begin{array}{l}\text { Civic } \\
\text { worth }\end{array}$} & Stakeholder Perspective & & & & \\
\hline & Civil Behavior & & & & \\
\hline & Ethical Behavior & & & & \\
\hline \multirow{3}{*}{$\begin{array}{l}\text { Market } \\
\text { worth }\end{array}$} & Desires and Needs & & & & \\
\hline & Expand Business & & & & \\
\hline & Business Knowledge & & & & \\
\hline \multirow{2}{*}{$\begin{array}{l}\text { Worth of } \\
\text { fame }\end{array}$} & Goodwill & & & & \\
\hline & Communication & & & & \\
\hline
\end{tabular}

Comments: White = no statements; light gray = a couple of statements; dark grey = a few statements; black = several statements. Since the data do not qualify for quantitative content analysis, the strength is estimated.

As shown in Table 2, the organizations expressed a multitude of values in what kind of traits, behaviors, and skills they were evaluating, and all of them expressed signifying values connecting to at least four of the orders of worth: industrial, domestic, inspired, and civic. The manufacturing company, and, to a modest extent also the state agency, expressed worth belonging also to the Worlds of Market and Fame. From an institutional logics approach, it makes sense that a private manufacturing company competing on the global market for goods values performances connecting to market worth (Thornton et al. 2012; cf. Townley 1997). This is less obviously the case for organizations in the public sector. However, under NPM pressure, they may want to polish their 
reputation and encourage employees to be more 'user-friendly' by noticing what needs and desires citizens have. If that is the case, however, it seems strange that neither the municipality nor the hospital takes any market or fame values into account. In addition, the manufacturing company put a strong emphasis on civic and inspired worth, indicating the existence of multiple logics (Goodrick \& Reay 2011). This is not surprising given that the development of emotional and cognitive capitalist organizations is headed by private companies (Boltanski \& Chiapello 2005).

\section{Concluding discussion}

The purpose of this study was to explore, describe, and explain the (e)valuation of employees in yearly salary review, by focusing on what characteristics that are prized and (ap)praised in organizational performance criteria. This approach aimed to grasp what signifying values make up 'employees of greatness' in contemporary capitalist and public organizations, that is, to understand what employees are expected and encouraged to be and to do to be highly valued co-workers. This concluding section synthesizes the results to draw some more general conclusions. The first conclusion concerns how employees of greatness are signified by performance appraisal criteria, and the second connects to the discussion of the changes in capitalist organizations of the last decades. The paper ends with a discussion of some implications of the study in relations to the theoretical approaches of orders of worth (Boltanski \& Chiapello 2005; Boltanski \& Thévenot 2006).

\section{Employees of greatness - signifying values in performance appraisal criteria}

From a valuation studies approach, this study has shown that performance appraisal criteria reviews are (e) valuations of employees' yearly performance, and a means to distinguish high performance from low performance (Lamont 2012). For a majority of white-collar employees in the private sector, as well as for a majority of all public sector employees in Sweden, these performance appraisals are not only, as Townley (1997) put it, instruments for developing employees, but also judgmentally in determining wages. There is a strong link between the multiple qualitative and quantitative economic valuations of the employee; the employees are prized and (ap)praised at the same moment (Stark 2017). As strategic documents, performance criteria are a means to steer and encourage employees towards worthy performances through prize and praise, and to motivate them to strive for greatness. They are tools for constructing 'employees of greatness', in a dual sense: abstractly through the construction of the ideal worker, and concretely through making employees strive towards the ideal (Hoedemaekers \& Keegan 2010).

The analysis disclosed a plethora of warranted traits, attitudes, behaviors, and performances. Together, they become a yardstick for the (e)valuation of employees, and may be used to theoretically reconstruct a joint ideal of 'employees of greatness'. With reference to the six orders of worth in Boltanski and Thévenot (2006), such an ideal signifies greatness in individuals who (i) have adequate knowledge and competence, and continuously develops it, who stay goal-oriented and perform with high and increasingly good quality, 
contribute to the team and the whole of the operations (industrial); (ii) are not only loyal to co-workers, but also the workplace and the whole organization (domestic); (iii) are driven by curiosity, inspiration, and are innovative (inspired); (iv) take a stakeholder perspective and behave in a civic and ethical manner (civic); (v) know the organization's business and try to expand it by taking the desires and needs of the customer or user into account (market); and (vi) try to create goodwill for the organization by communicating convincingly with customers and stakeholders (fame). This is, of course, a theoretical abstraction, far from demands put on an actual single employee, and even from what is expressed in single organizations. Still, as an ideal type, it makes it possible to grasp and understand what contemporary organizations value in employees.

Altogether, the organizations evaluate and value quite similar behaviors, attitudes, traits, and skills. However, there were some differences, since not all organizations put similar emphasis on all orders of worth. For instance, the municipality and the hospital lacked values connecting to the worth of market and fame. It is also interesting to note that industrial worth is not only a relevant frame of reference for the manufacturing company but even more so for the public sector organizations. Correspondingly, the civic and inspired worth is even more emphasized in the manufacturing company than in the public sector organizations.

To some extent, these results contradict the theoretical expectations from which the selection of the cases was made. The four organizations - a municipality, a regional hospital, a state agency, and a private manufacturing company - represent different institutional contexts with different institutional logics (Thornton et al. 2012; cf. Townley 1997). Therefore, a greater variation of worth was expected to be found. According to theory, state bureaucracies, the healthcare sector, and private manufacturing companies are embedded in different value spheres, which influences organizational norms, interests, identities, and practices (Cloutier \& Langley 2013). Organizations operating in different institutional contexts would be expected to pursue and promote varying worth and diverse signifying values, and also to resist or at least edit or adapt selectively from external pressures. However, the results provide little evidence of that being the case. In contrast to Townley (1997), who showed that there was - at least two decades ago resistance from UK public organizations to fully adjust to private capitalist performance appraisal, we find striking similarities between private and public organizations in their usage of performance appraisals and their constructs of the employee of greatness. These results imply conformity, and thus a quite strong isomorphic tendency, in what is considered worthy in terms of expectations of labor; this needs to be further explained.

\section{Converging capitalisms - the function of performance appraisal}

Under the spirit of industrial capitalism, employers and organizations demanded employees who were punctual, effective, reliable, and physically strong (Jensen \& Prieur 2016; cf. Rees Davies \& Flink 2014). Contemporary labor markets and employing organizations now ask for more. Older principles suggested 'turn up and you'll get paid, turn up for several years and you'll get paid more', while more recent principles imply 'turn up and perform to a highly satisfactory standard and you'll get paid more' (Corby et al. 2009:7). This represents a change from rewarding the job to rewarding the person. In addition to this, whereas one strand of research stress increased demands on emotional 
labor (Hochschild 1983) in what has been called emotional capitalism (Illouz 2007, 2018), others emphasize knowledge and cognitive labor in the era of cognitive capitalism (Moulier Boutang 2011). Jensen and Prieur (2016) summarized it as 'The commodification of the personal'.

Out of the 19 aspects of worth that emerged from the content analysis, only three belong to the industrial mode of capitalism; 10 of the aspects capture worth that fits well into the sphere of emotional capitalism, while six connect to cognitive capitalism. In line with Jensen and Prieur $(2016,104)$, we conclude that the contemporary labor market is a combination of capitalisms, 'where skills, traits, and characteristics hitherto considered irrelevant to the sphere of production, like co-operative skills and subdued handling of emotions, become central to the production of value'. However, the new world of work has not only affected 'liberated' capitalist firms (DiMaggio 2001), as a corresponding transformation has occurred in public sector organizations, introducing more of industrial, market and even fame-order of worth elements into that world of work (Brunsson 2009; Hood 1991; Pollitt \& Bouckaert 2011; Townley 1997).

This line of reasoning is similar to Boltanski and Chiapello's (2005) discussion of the 'third wave' of capitalism. Thus, the employee of greatness construct is caused by an increasing convergence in the (capitalist) organization, in both private and public sectors, in which emotional and cognitive worth of labor superimposes, rather than substitutes, traditional industrial worth (see Figure 1). The ideals and values from emotional and cognitive capitalism, which increasingly penetrate the world of industrial capitalism, are not intended to counterbalance the emphasis on productivity and market principles, but rather to be additional means of increasing it through a focus on a broader set of traits, attitudes, and behavior among the employees: to produce, sell, and serve with efficiency and yet with knowledge, commitment and a smile.

As discussed by Boltanski and Chiapello (2005), the employee in contemporary organizations needs to be fluid, in the sense of adapting, developing, flexibilizing, emotionalizing, and reconstructing him/herself to meet the expectations of the organization. This points to the function of performance appraisal in the context of converging capitalisms (Hoedemaekers \& Keegan 2010) and to the idea of how perpetual organizational reform has become routine (Brunsson 2009). Similarly to how contemporary organizations continuously strive to improve towards (im)possible ideals, the employee of today is encouraged to improve toward an ideal of employee greatness and is not only priced but also (ap)praised in the yearly (e)valuations. The point is not that employees are able, or even expected, to reach that goal, but that the (im)possible ideal is a yardstick against which one is measured and always found wanting.

\section{The converging divergence of logics - one or multiple worlds of worth}

There are multiple logics at work in the constructions of the ideal of employee greatness (cf. Goodrick \& Reay 2011). The assumptions that some logics apply more to certain institutional domains or context (Cloutier \& Langley 2013) only have a bearing on a few aspects in the present study. The results point to converging organizational values: when bureaucracies are guided by management by objectives, lean, internal marketization, customer service ideals, and performance reviews, the distance between public organizations and industrial capitalist organizations decreases (Brunsson 2009; 
Figure I Values from emotional and cognitive capitalism penetrate industrial capitalism.

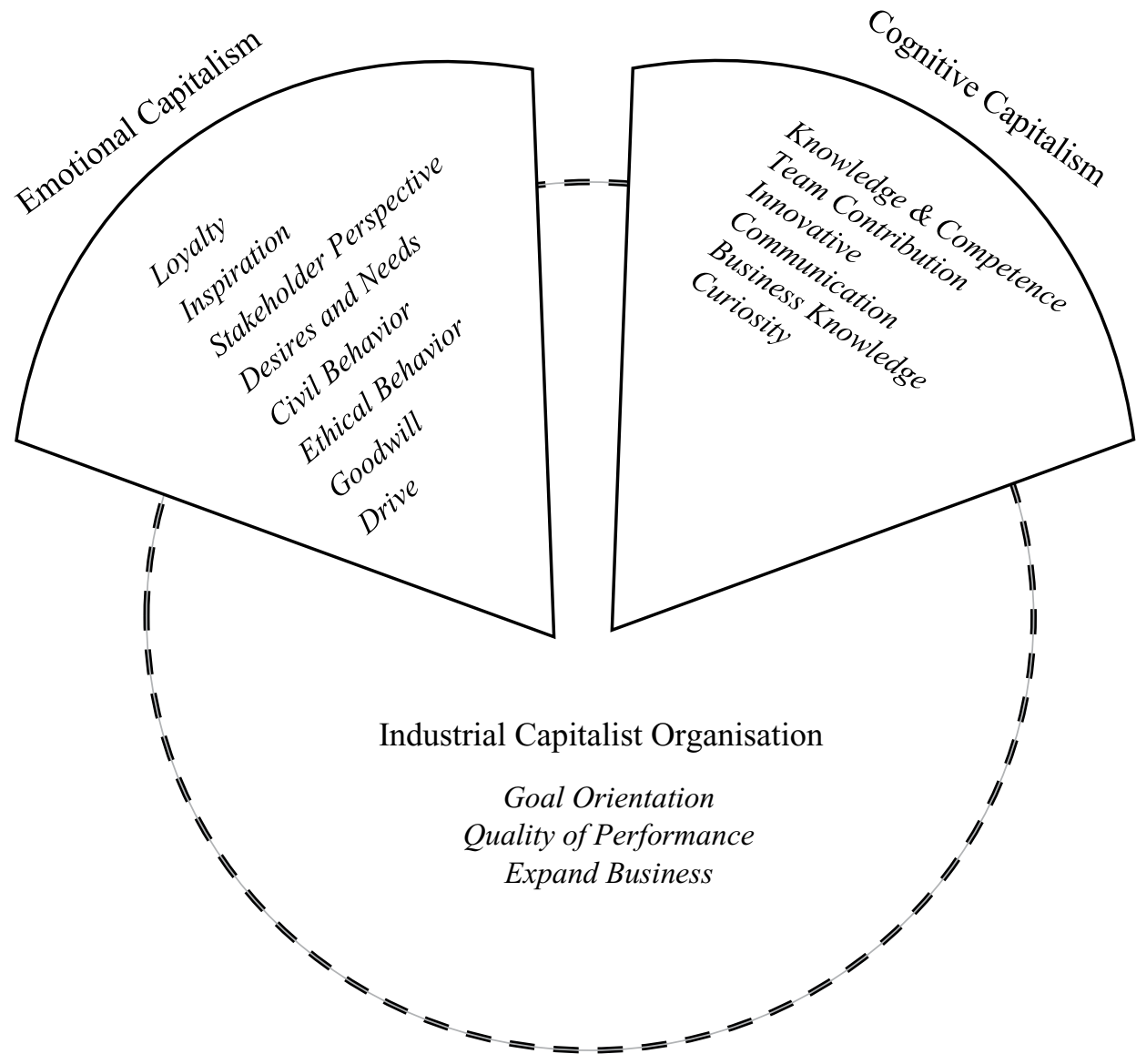

Hood 1991; Pollitt \& Bouckaert 2011). Similarly, when professionalism is not only about autonomy and discretionary decision-making but also about organizational interest and discipline, another indication of such convergences between institutional domains is obvious (Evetts 2011; Fournier 1999). This convergence implies that public sector organizations mimic the capitalist organization of private firms.

It may appear that this analysis has reinvented the seventh world - the Project Cité - that Boltanski and Chapiello (2005) added to the six original worlds of Boltanski and Thévenot (2006), as a response to what they saw as the emergence of a new spirit of capitalism. Therefore; why were the six original worlds of worth used in the analysis, when the findings and the points made are so close to the construct of Project Cite, and to Boltanski and Chapiello's (2005) argument that the industrial world of worth has transformed by these new values? Drawing on the findings in this study, the seventh regime seems to be more of an empirical type, combining elements from the original six orders of worth with some new ones, and not 'a world' that can be put on par with the others as mutually exclusive ideal types. 
Performance appraisal criteria belong primarily to the Industrial World, as they focus on efficiency and productivity in employee performance. Still, this study shows the value of exploring how signifying values in the different worlds of worth are used within the industrial regime. Thus, the main theoretical contribution in this study is the value of exploring for multi-dimensionality within each of the six orders of worth, to disclose how signifying values from the distinguished worlds integrate and permeate each other.

\section{References}

Armstrong, M. (2009). Armstrong's handbook of performance management: an evidence-based guide to delivering high performance, London: Kogan Page Publishers.

Aspers, P. \& Beckert, J. (2011). Values in markets, In J. Beckert \& P. Aspers (eds), The Worth of Goods. Valuation \& Pricing in the Economy, Oxford: Oxford University Press.

Autor, D. H., Levy, F. \& Murnane, R. J. (2003). The skill content of recent technological change: An empirical exploration, The Quarterly Journal of Economics 118(4): 1279-1333. doi: https://doi.org/10.1162/003355303322552801.

Baccaro, L. \& Howell, C. (2017). Trajectories of Neoliberal Transformation. European Industrial Relations Since the 1970s, Cambridge: Cambridge University Press.

Beckert, J. \& Aspers, P. (eds). (2011). The Worth of Goods. Valuation \& Pricing in the Economy, Oxford: Oxford University Press.

Beckert, J. \& Musselin, C. (eds.) (2013). Constructing Quality: The Classification of Goods in Markets, Oxford: Oxford University Press.

Beckert, J. (2011). Where do prices come from? Sociological approaches to price formation, Socio-Economic Review 9(4): 757-786. doi: https://doi.org/10.1093/ser/mwr012.

Bengtsson, M. \& Berglund, T. (2012). Labour market policies in transition: From social engineering to standby-ability. In B. Larsson, M. Letell, and H. Thörn (eds), Transformations of the Swedish Welfare State. From Social Engineering to Governance? London, UK: Palgrave Macmillan.

Biswas, U. N., Allard, K., Pousette A. \& Härenstam, A. (2017). Understanding Attractive Work in a Globalized World: Studies from India and Sweden, Singapore: Springer.

Boltanski L. \& Thévenot, L. (2006/1991). On Justification. Economies of Worth, Princeton: Princeton University Press.

Boltanski, L. \& Chiapello, E. (2005). The New Spirit of Capitalism, London: Verso.

Braun, V. \& Clarke, V. (2006). Using thematic analysis in psychology, Qualitative Research in Psychology 3(2): 77-101. doi: https://doi.org/10.1191/1478088706qp063oa.

Brunsson, N. (2009). Reform as Routine: Organizational Change and Stability in the Modern World, Oxford: Oxford University Press.

Chatelain-Ponroy S., Mignot-Gérard S., Musselin C. \& Sponem S. (2018). Is commitment to performance-based management compatible with commitment to university 'publicness?' Academics values in French universities, Organization Studies 39(10): 1377-1401. doi: https://doi.org/10.1177/0170840617717099.

Cloutier, C. \& Langley, A. (2013). The logic of institutional logics: insights from French Pragmatist sociology, Journal of Management Inquiry 22(4): 360-380. doi: https://doi. org/10.1177/1056492612469057.

Corby, S., Palmer, S. \& Lindop, E. (2009). Trends and tensions: an overview. In S. Corby, S. Palmer \& E. Lindop (Eds.) Rethinking Reward, Basingstoke: Palgrave Macmillan.

De Munck, J., \& Zimmermann, B. (2015). Evaluation as practical judgment, Human Studies 38: 113-135. doi: https://doi.org/10.1007/s10746-014-9325-1.

Dewey, J. (1939). Theory of valuation, International Encyclopedia of Unified Science 2(4). 
DiMaggio, P. (ed.) (2009). The Twenty-first-century Firm: Changing Economic Organization in International Perspective, Princeton: Princeton University Press.

Eurofound (2016). Changes in Remuneration and Reward Systems, Luxembourg: Publications Office of the European Union.

Evetts, J. (2011). A new professionalism? Challenges and opportunities, Current Sociology 59(4): 406-422. doi: https://doi.org/10.1177/0011392111402585.

Fleming, P. \& Sturdy, A. (2009). 'Just be yourself!' Towards neo-normative control in organisations?, Employee Relations 31(6): 569-583. doi: https://doi.org/10.1108/014254509 10991730.

Fournier, V. (1999). The appeal to 'professionalism' as a disciplinary mechanism, The Sociological Review 47(2): 280-307. doi: https://doi.org/10.1111/1467-954x.00173.

Furåker, B. (2012). Theoretical and Conceptual Considerations on Work Orientations, In B. Furåker, K. Håkansson \& J. C. Karlsson (eds.), Commitment to Work and Job Satisfaction, New York: Routledge.

Garsten, C. \& Jacobsson, K. (2004). Learning to be employable: an introduction, In C. Garsten \& K. Jacobsson. Learning to be Employable: New Agendas on Work, Responsibility and Learning in a Globalized World, Basingstoke: Palgrave Macmillan.

Gomez-Mejia, L. R., Berrone, P. \& Franco-Santos, M. (2010). Strategic Compensation and Performance, New York: ME Sharpe.

Goodrick, E. \& Reay, T. (2011). Constellations of institutional logics: changes in the professional work of pharmacists, work and occupations 38(3): 372-416. doi: https://doi. org/10.1177/0730888411406824.

Heneman, R. L. (2003). Job and work evaluation: a literature review, Public Personnel Management 32(1), 47-71. doi: https://doi.org/10.1177/009102600303200103.

Hochschild, A. R. (1983). The Managed Heart, Berkeley: University of California Press.

Hoedemaekers, C. \& Keegan, A. (2010). Performativity pinned down: studying subjectivity and the language of performance, Organization Studies 31(08): 1021-1044. doi: https:// doi.org/10.1177/0170840610376145.

Hood, C. (1991). A public management for all seasons, Public Administration 69(1): 3-19. doi: https://doi.org/10.1111/j.1467-9299.1991.tb00779.x.

Illouz, E. (2007). Cold Intimacies: The Making of Emotional Capitalism, Cambridge: Polity Press.

Illouz, E. (2018). Introduction, In E. Illouz (ed.), Emotions as Commodities: Capitalism, Consumption and Authenticity, London: Routledge.

Jensen, S. Q. \& Prieur, A. (2016). The commodification of the personal: labour market demands in the era of neoliberal postindustrialization, Distinktion: Journal of Social Theory 17(1): 94-108. doi: https://doi.org/10.1080/1600910x.2015.1082922.

Jirjahn, U. \& Poutsma, E. (2013). The use of performance appraisal systems: evidence from Dutch establishment data, Industrial Relations: A Journal of Economy and Society 52(4): 801-828. doi: https://doi.org/10.1111/irel.12036.

Karpik, L. (2010). Valuing the Unique. The Economics of Singularities, Princeton: Princeton University Press.

Lamont, M. (2012). Toward a comparative sociology of valuation and evaluation, Annual Review of Sociology 38: 201-221. doi: https://doi.org/10.1146/annurev-soc-070 308-120022.

Lapidus, J. (2015). An odd couple: individual wage setting and the largest Swedish trade union, Labor History 56(1): 1-21. doi: https://doi.org/10.1080/0023656x.2015.991556.

Larsson, B., M. Letell \& H. Thörn. (2012). Transformations of the Swedish Welfare State. From Social Engineering to Governance? New York, US: Palgrave Macmillan.

Larsson, B., Ulfsdotter Eriksson, Y. \& Adolfsson, P. (2017) Personalvetenskapliga perspektiv på lön och belöning, Stockholm: Liber. 
Lindgren, G. (2001). 'Alone in the team'. A Sociological Perspective on New Organizational Models within Health Care, In A. Thörnquist (ed.), Work Life, Work Environment and Work Safety in Transition, Stockholm: National Institute for Working Life.

Madden, J. F. \& Vekker, A. (2017). Output-based performance pay, performance-support bias, and the racial pay gap within a large retail stock brokerage, Industrial Relations: A Journal of Economy and Society 56(4): 662-687. doi: https://doi.org/10.1111/irel.12191.

Mintzberg, H. (1983). Structure in Fives: Designing Effective Organizations, Englewood Cliffs: Prentice-Hall, Inc.

Moulier Boutang, Y. (2011). Cognitive Capitalism, Cambridge: Polity.

Pollitt, C. \& Bouckaert. G. (2011). Public Management Reform, Oxford: Oxford University Press.

Rees Davies, A. R. \& Frink, B. D. (2014). The origins of the ideal worker: the separation of work and home in the United States from the market revolution to 1950, Work and Occupations 41(1): 18-39. doi: https://doi.org/10.1177/0730888413515893.

Schreier, M. (2013). Qualitative Content Analysis, In U. Flick (ed.), The SAGE Handbook of Qualitative Data Analysis, Los Angeles: Sage.

Sennett, R. (1998). The Corrosion of Character: The Personal Consequences of Work in the New Capitalism, New York: WW Norton \& Company.

Spano, A. \& Monfardini, P. (2018). Performance-related payments in local governments: do they improve performance or only increase salary?, International Journal of Public Administration, 41(4): 321-334. doi: https://doi.org/10.1080/01900692.2016.1265982.

Stark, D. (2009). The Sense of Dissonance. Accounts of Worth in Economic Life, Princeton: Princeton University Press.

Stark, D. (2017). For what it's worth, In C. Cloutier, J-P Gond, \& B. Leca (eds.), Justification, Evaluation and Critique in the Study of Organizations: Contributions from French Pragmatist Sociology, Bingley: Emerald.

Storey, J. \& Sisson, K. (2005). Perfomance-related pay, In G. Salaman, J. Storey \& J. Billsberry, (eds.), Strategic Human Resource Management. Theory and Practice, London: Open University.

Thörnqvist, C. (1998). The Swedish Discourse on Decentralisation of Labour Relations, In D. Fleming \& C. Thörnqvist (eds.), Global Redefining of Working Life - A New Nordic Agenda for Compentence and Participation, Köpenhamn: Nordiska Ministerrådet.

Thornton, P. H., Ocasio, W. \& Lounsbury. M. (2012). The Institutional Logics Perspective, Oxford: Oxford University Press.

Townley, B. (1997). The institutional logic of performance appraisal, Organization Studies 18(2): 261-285. doi: https://doi.org/10.1177/017084069701800204.

Ulfsdotter Eriksson, Y., Larsson, B. \& Adolfsson, P. (2019). Implementing and integrating policies on performance-based pay: coordinating the "One-Employer Approach" in a Swedish municipality, International Journal of Public Administration, doi: https://doi.org /10.1080/01900692.2019.1570523.

Ulfsdotter Eriksson, Y., Larsson, B. \& Adolfsson, P. (2020), Under the Surface of Individual and Differentiated Pay in Sweden: a Zero-Sum Game of Performance-Based Pay? British Journal of Industrial Relations. doi: https://doi.org/10.1111/bjir.12561.

Voswinkel, S. (2012). 'Recognition' and 'interest': a multidimensional concept in the sociology of work, Distinktion: Journal of Social Theory 13(1): 21-41. doi: https://doi.org/10.1080/ 1600910x.2012.640594. 